\title{
Populations of Odontesthes (Teleostei: Atheriniformes) in the Andean region of Southern South America: body shape and hybrid individuals
}

\author{
Cecilia Conte-Grand ${ }^{1}$, Julie Sommer ${ }^{2}$, Guillermo Ortí $^{3}$ and Víctor Cussac ${ }^{4}$
}

\begin{abstract}
The original distribution area of the Patagonian 'pejerrey' Odontesthes hatcheri has been subjected to the introduction of a related species; the Bonaerensean 'pejerrey' Odontesthes bonariensis. This species currently coexists with $O$. hatcheri in lakes and reservoirs, and can interbreed and produce fertile hybrid offspring. The purposes of this study were; a) the extensive sampling of Patagonian and Andean-Cuyan populations of pejerrey, b) the species identification according to taxonomic key, c) validation of taxonomic results on the basis of mitochondrial DNA composition, and d) applying morphometric analysis to explore the effects of hybridization and environmental conditions on body shape. Cytochrome $b$ sequence analysis showed a high degree of genetic divergence between species and low intraspecific variation in $O$. hatcheri. Geometric Morphometric Analyses detected shape differences in agreement with diagnostic characteristics of each species. Putative hybrids exhibiting intermediate diagnostic characteristics were identified by Geometric Morphometric Analysis. Significant regressions between body shape and total phosphorus and altitude were found, suggesting a dependence on trophic web structure. This multi-level approach suggests the introgression of $O$. bonariensis into several $O$. hatcheri populations throughout Patagonia. Managers should take this into account when considering further exotic introductions into regions where non-native fishes have not yet become established.
\end{abstract}

La distribución original del 'pejerrey' patagónico Odontesthes hatcheri ha sido sometida en las últimas décadas a la introducción de una especie relacionada; el 'pejerrey' Bonaerense Odontesthes bonariensis. Ambas especies coexisten actualmente en algunos lagos y embalses debido a prácticas de siembra y pueden cruzarse y producir progenie híbrida y fértil. Los propósitos de este estudio fueron a) un amplio muestreo de las poblaciones patagónicas y andino-cuyanas del pejerrey, b) la identificación de las especies de acuerdo con la clave taxonómica, c) la validación de los resultados taxonómicos sobre la base de la composición del ADN mitocondrial y d) aplicar el análisis morfométrico para explorar los efectos de la hibridización y las condiciones ambientales sobre la forma corporal. El análisis de la secuencia del Citocromo $b$ mostró un alto grado de divergencia genética entre ambas especies y una muy baja variación intraespecífica en $O$. hatcheri. El análisis de la Morfometría Geométrica detectó diferencias de forma coincidentes con las características diagnósticas de cada especie. Presuntos híbridos exhibiendo características diagnósticas intermedias fueron identificados por el análisis de la Morfometría Geométrica. Regresiones significativas entre la forma corporal y la concentración total de fósforo y la altitud fueron halladas, sugiriendo una dependencia con la estructura de la trama trófica. Este enfoque múltiple sugiere la introgresión de genes de $O$. bonariensis dentro de varias poblaciones de $O$. hatcheri a lo largo de la Patagonia. Las autoridades de aplicación deberían tomar en cuenta estos riesgos al momento de considerar nuevas introducciones de especies exóticas en regiones donde estas especies no se encuentren previamente establecidas.

Keywords: Geometric morphometrics, Patagonia, Pejerrey, Stocking.

\section{Introduction}

The Patagonian pejerrey, Odontesthes hatcheri (Eigenmann, 1909) is a native freshwater species from the Andean Region of southern South America (Dyer, 2000; López et al., 2008), encompassing a vast latitudinal range, from $27^{\circ} \mathrm{S}$ to $54^{\circ} \mathrm{S}$. This species is commonly found in rivers, lakes, and reservoirs of both Atlantic and Pacific Patagonian drainages (Aigo et al., 2008).

The native distribution area of the Patagonian pejerrey (Fig. 1) has been subject to stocking practices, with Odontesthes bonariensis (Valenciennes, 1835) stocking

\footnotetext{
${ }^{1}$ Instituto de Investigaciones en Biodiversidad y Medioambiente (INIBIOMA), Universidad Nacional del Comahue - Consejo Nacional de Investigaciones Científicas y Técnicas (CONICET), Bariloche, 8400 Río Negro, Argentina. ceciliacontegrand@yahoo.com

${ }^{2}$ School of Biological Sciences, University of Nebraska, Lincoln NE 68588, USA. juliesommer@yahoo.com

${ }^{3}$ The George Washington University, 2023 G Street NW, Washington DC 20052, USA. guilleorti@gmail.com

${ }^{4}$ Instituto de Investigaciones en Biodiversidad y Medioambiente (INIBIOMA), Universidad Nacional del Comahue - Consejo Nacional de Investigaciones Científicas y Técnicas (CONICET), Bariloche, 8400 Río Negro, Argentina. cussacve@comahue-conicet.gob.ar
} 
carried out by three hatcheries (Estación Hidrobiológica de Chascomús $35^{\circ} 36^{\prime} \mathrm{S}, 58^{\circ} 01^{\prime} \mathrm{W}$, Estación de Piscicultura de Embalse $32^{\circ} 13^{\prime} \mathrm{S}, 64^{\circ} 29^{\prime} \mathrm{W}$, and Estación de Piscicultura

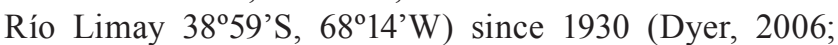
Crichigno et al., 2013). Crichigno et al. (2013) differentiated $O$. hatcheri, $O$. bonariensis and intermediate individuals on the basis of head shape. The taxonomic categories included a non-negligible number of individuals considered misclassified cases. The closer the hatcheries participating in stocking programs (Estación de Piscicultura de Embalse and Estación de Piscicultura Río Limay) were to the sampling site, the higher the percentage of misclassified individuals.

Odontesthes bonariensis, a commercially important species that has been used extensively in aquaculture since the early 1900s (Somoza et al., 2008), is a dominant species in the limnetic zone of the 'lagunas' (Gómez et al., 2007) of Buenos Aires Province in Argentina and in diverse environments within the Plata-Paraná basin (Fig. 1). This ubiquitous species is highly valued as food and as a sport fish. In consequence, it has been introduced in Argentina and Chile and also exported overseas to Japan and Italy (López et al., 1991; Somoza et al., 2008). This species is able to establish populations in environments where mean summer air temperatures are higher than $20^{\circ} \mathrm{C}$ (Cussac et al., 2009). The southernmost locality known for $O$. bonariensis in Patagonia is the Reservoir Ezequiel Ramos Mexía on the Limay river $\left(39^{\circ} 30^{\prime} \mathrm{S}, 69^{\circ} 00^{\prime} \mathrm{W}\right.$, Aigo et al., 2008).

Both species have disjoint natural distributions (Fig. 1); $O$. hatcheri in the southwest and $O$. bonariensis in the north east (Baigún \& Ferriz, 2003; Dyer, 2006; Aigo et al., 2008), and both are remarkably tolerant of high salinity levels but not of sea water (Tsuzuki et al., 2000a, b; Gómez \& Ferriz, 2001). Genetic data from Sommer et al. (2010) indicate that $O$. hatcheri has a closer relationship with marine species than with $O$. bonariensis. Both species hybridize in captivity (Strüssmann et al., 1997a) and probably also in the wild (Dyer, 2000). This suggests that the extent of hybridization in natural habitats where both species coexist may be significant (Strüssmann et al., 1997a).

The successful interbreeding of hybrids with one or both parental forms leads to introgression of varying degrees (Turner, 1999). To characterize individuals along such a continuum, and to account for various types of hybrids, many authors have resorted to multivariate analysis (Crespin \& Berrebi, 1999). Multidimensional morphology (Crespin \& Berrebi, 1999) and geometric morphometrics (Valentin et al., 2002; Bart Jr et al., 2010; Tobler \& Carson, 2010) have proven useful tools in the study of the morphological transition across hybrid zones between species.

The aim of this study is to review the taxonomic status of native populations of $O$. hatcheri after the introduction of $O$. bonariensis. The study involves; a) extensive sampling of Patagonian and Andean-Cuyan populations of the Patagonian pejerrey, b) species identification according to taxonomic key, c) genetic analyses used to validate taxonomic results based on the mitochondrial DNA composition, and d) morphometric analysis used to explore the effects of hybridization and environmental conditions on body shape.

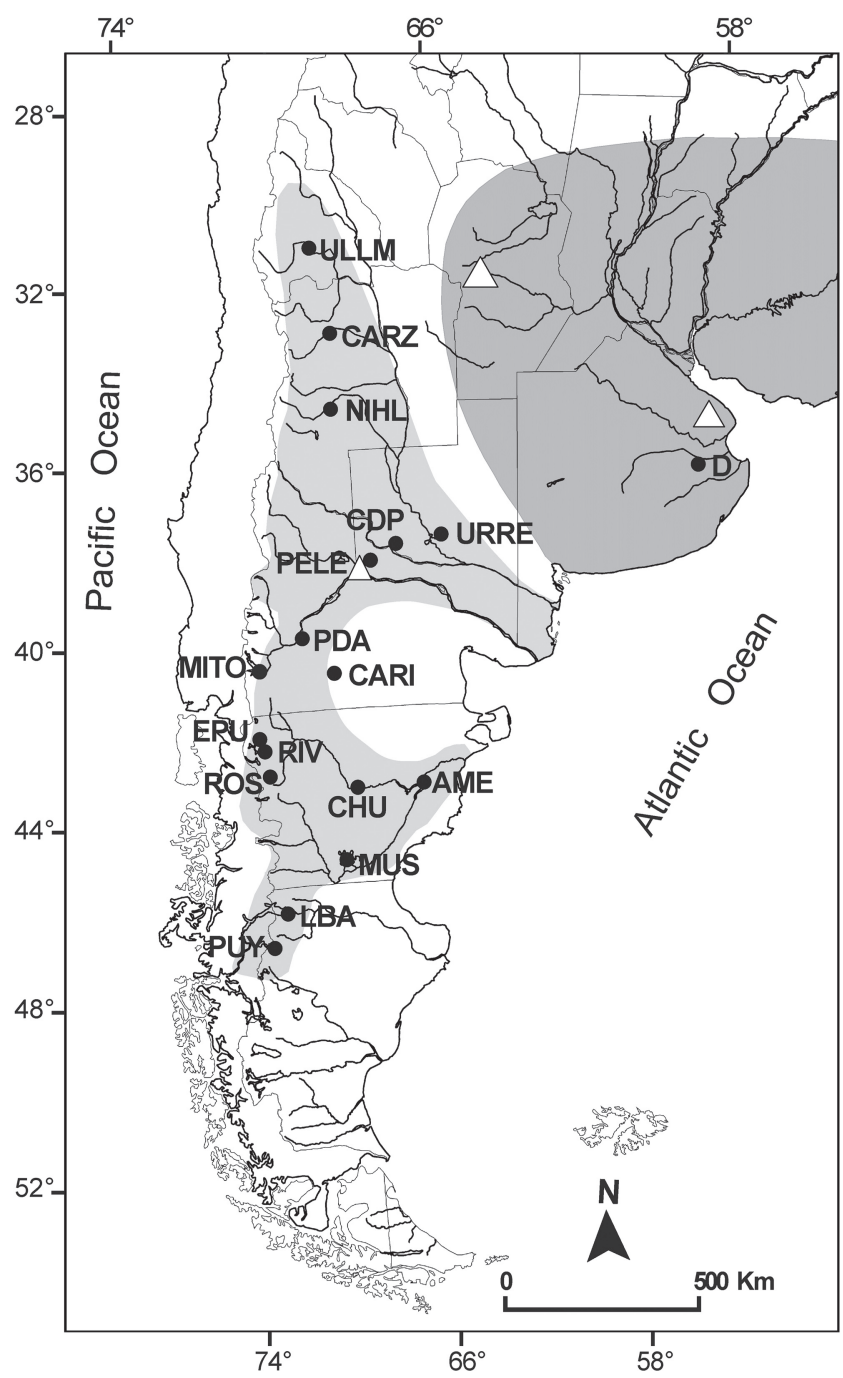

Fig. 1. Distribution of $O$. hatcheri (light gray) and $O$. bonariensis (dark gray) described by Dyer (2006) and sampling localities: ULLM, Ullum Reservoir; CARZ, Carrizal Reservoir; NIHL, Nihuil Reservoir; D, Lake San Lorenzo; URRE, Lake Urre Lauquen; CDP, Casa de Piedra Reservoir; PELE, Lake Pellegrini; PDA, Piedra del Aguila Reservoir; MITO, Lake Morenito; CARI, Lake Carilafquen; EPU, Lake Epuyén; RIV, Lake Rivadavia; ROS, Lake Rosario; AME, Florentino Ameghino Reservoir; CHU, Chubut River at Los Altares; MUS, Lake Musters; LBA, Lake Buenos Aires; PUY, Lake Pueyrredón. White triangles show the location of the three hatcheries (Estación Hidrobiológica de Chascomús $35^{\circ} 36^{\prime}$ 'S, 58 $01^{\circ}$ 'W, Estación de Piscicultura de Embalse $32^{\circ} 13^{\prime} \mathrm{S}, 64^{\circ} 29^{\prime} \mathrm{W}$, and Estación de Piscicultura Río Limay 3859'S, 68¹4'W), sources of stocking practices. 


\section{Materials and Methods}

Collection sites and sampling procedures. Fish samples were obtained from 18 localities throughout the Andean Region, covering most of the native distribution of $O$. hatcheri. Individuals were caught using seine or gill nets in streams or littoral areas of lakes and reservoirs (Table 1, Fig. 1). A sample from a natural population of $O$. bonariensis was obtained from the native range of this species (Lake San Lorenzo, locality D in Fig. 1, Table 1) as a reference. To study interactions between the two species and the formation of hybrids, four localities were targeted where both species were present (NIHL, URRE, CDP, PELE, in Fig. 1). Captured fish were immediately killed by an overdose of anesthetic (benzocaine 1:10000). Digital images of the left side of the body were taken for each fresh specimen, taking care to minimize parallax error. Fish were measured (Standard Length $=\mathrm{SL}$ ), weighed, and Condition Factor (body mass . $\mathrm{SL}^{-3}$ ) was calculated. Tissue samples (muscle) were preserved in $96 \%$ ethanol for DNA analysis. Species identities were determined following the dichotomous key proposed by Dyer (2006). Specimens corresponding to Lake Pueyrredón, the type locality of $O$. hatcheri (Ringuelet et al., 1967), were deposited in Facultad de Ciencias Naturales y Museo, Universidad Nacional de La Plata, Argentina (Voucher Museum ID: MLP 9858 to MLP 9877). The same Sample ID was used to include these individuals in The Barcode of Life Data System (Ratnasingham \& Hebert, 2007).

Table 1. Sampling localities, basins, latitude, longitude, mean summer air temperature 1961-1990 (Temp, data from Servicio Meteorológico Nacional, Argentina, www.smn.gov.ar), species identification, and SL of Odontesthes specimens used in this study. All river drainages flow to the Atlantic, unless otherwise noted (Pacific). OB: O. bonariensis, OH: O. hatcheri, Hy: presumptive hybrids, showing key characters of both species; CA: Cluster Analysis; GMA: Geometric Morphometrics Analysis; N: number of specimens. In bold, differences between key, genetic, and morphological criteria. Presumptive hybrids were highlighted as * in Fig. 3 and bold characters in Table 2.

\begin{tabular}{|c|c|c|c|c|c|c|}
\hline Sampling locality and river basin & $\begin{array}{l}\text { Latitude (S) } \\
\text { Longitude (W) }\end{array}$ & $\begin{array}{l}\text { Temp } \\
\left({ }^{\circ} \mathrm{C}\right)\end{array}$ & $\begin{array}{l}\text { Species } \\
\text { based on key } \\
\text { characters }(\mathrm{N})\end{array}$ & $\begin{array}{l}\text { Species based } \\
\text { on mtDNA }(\mathrm{N})\end{array}$ & $\begin{array}{l}\text { Species based } \\
\text { on CA applied to } \\
\text { GMA data }(\mathrm{N})\end{array}$ & $\begin{array}{l}\mathrm{SL}(\mathrm{cm})(\text { mean } \\
\text { and range) }\end{array}$ \\
\hline ULLM, Ullum Reservoir, Colorado basin & $\begin{array}{l}31^{\circ} 28^{\prime} \\
68^{\circ} 40^{\prime}\end{array}$ & 22 & $O B(25)$ & $O B(1)$ & $O B(25)$ & $\begin{array}{l}8.83 \\
(6.06-14.14)\end{array}$ \\
\hline CARZ, El Carrizal Reservoir, Colorado basin & $\begin{array}{l}33^{\circ} 20^{\prime} \\
68^{\circ} 43^{\prime}\end{array}$ & 22 & $O B(30)$ & $O B(1)$ & $O B(30)$ & $\begin{array}{l}17.00 \\
(13.62-30.90)\end{array}$ \\
\hline NIHL, El Nihuil Reservoir, Colorado basin & $\begin{array}{l}35^{\circ} 04^{\prime} \\
68^{\circ} 45^{\prime}\end{array}$ & 22 & $O H(12)$ & $\begin{array}{l}O B(2) \\
O H(7)\end{array}$ & $O H(12)$ & $\begin{array}{l}7.44 \\
(4.85-9.71)\end{array}$ \\
\hline D, Lake San Lorenzo; Salado del Sur basin & $\begin{array}{l}36^{\circ} 5^{\prime} \\
58^{\circ} 1\end{array}$ & $20-22$ & $O B(34)$ & $O B(2)$ & $O B(34)$ & $\begin{array}{l}19.66 \\
(15.54-23.98)\end{array}$ \\
\hline URRE, Lake Urre Lauquen; Colorado basin & $\begin{array}{l}38^{\circ} 5^{\prime} \\
65^{\circ} 50^{\prime}\end{array}$ & $22-24$ & OB (6) & $\begin{array}{l}\mathrm{OB}(2) \\
\mathrm{OH}(4)\end{array}$ & $\begin{array}{l}\mathrm{OB}(4) \\
\text { OH (1) }\end{array}$ & $\begin{array}{l}12.48 \\
(7.05-16.35)\end{array}$ \\
\hline CDP, Casa de Piedra Reservoir, Colorado basin & $\begin{array}{l}38^{\circ} 15^{\prime} \\
67^{\circ} 30^{\prime}\end{array}$ & $22-24$ & $\begin{array}{l}O B(1) \\
O H(8)\end{array}$ & $\begin{array}{l}O B(1) \\
O H(7)\end{array}$ & $\begin{array}{l}O B(1) \\
O H(8)\end{array}$ & $\begin{array}{l}7.75 \\
(3.92-26.58)\end{array}$ \\
\hline PELE, Lake Pellegrini; Negro basin & $\begin{array}{l}38^{\circ} 41^{\prime} \\
67^{\circ} 59^{\prime}\end{array}$ & 22 & $\begin{array}{l}\text { Hy (26) } \\
O H(19)\end{array}$ & $\begin{array}{l}\boldsymbol{O B}(\mathbf{5}) \\
O H(18)\end{array}$ & $\begin{array}{l}O B(6) \\
O H(36)\end{array}$ & $\begin{array}{l}27.51 \\
(22.32-39.40)\end{array}$ \\
\hline PDA, Piedra del Aguila Reservoir; Negro basin & $\begin{array}{l}40^{\circ} 24^{\prime} \\
70^{\circ} 6\end{array}$ & $16-18$ & $\mathrm{OH}(30)$ & & $O H(30)$ & $\begin{array}{l}9.46 \\
(12.20-7.80)\end{array}$ \\
\hline MITO, Lake Morenito; Negro basin & $\begin{array}{l}41^{\circ} 03^{\prime} \\
71^{\circ} 31^{\prime}\end{array}$ & $12-14$ & $\mathrm{OH}(27)$ & $\mathrm{OH}(6)$ & $O H(27)$ & $\begin{array}{l}31.37 \\
(21.77-38.00)\end{array}$ \\
\hline CARI, Lake Carilafquen Chica; endorheic basin & $\begin{array}{l}41^{\circ} 12^{\prime} \\
69^{\circ} 25^{\prime}\end{array}$ & $16-18$ & $O H(24)$ & $O H(2)$ & $O H(24)$ & $\begin{array}{l}20.93 \\
(26.70-14.03)\end{array}$ \\
\hline EPU, Lake Epuyen; Puelo basin (Pacific) & $\begin{array}{l}42^{\circ} 10^{\prime} \\
71^{\circ} 31^{\prime}\end{array}$ & $12-14$ & $O H(6)$ & $O H(11)$ & $O H(6)$ & $\begin{array}{l}5.02 \\
(4.14-5.63)\end{array}$ \\
\hline RIV, Lake Rivadavia; Futaleufú basin (Pacific) & $\begin{array}{l}42^{\circ} 30^{\prime} \\
71^{\circ} 45^{\prime}\end{array}$ & $12-14$ & $O H(28)$ & $O H(11)$ & $O H(28)$ & $\begin{array}{l}7.21 \\
(6.49-7.80)\end{array}$ \\
\hline ROS, Lake Rosario; Futaleufú basin (Pacific) & $\begin{array}{l}43^{\circ} 15^{\prime} \\
71^{\circ} 20^{\prime}\end{array}$ & $12-14$ & $\mathrm{OH}(27)$ & $O H(3)$ & $O H(27)$ & $\begin{array}{l}28.49 \\
(15.91-33.09)\end{array}$ \\
\hline AME, Florentino Ameghino Reservoir, Chubut basin & $\begin{array}{l}43^{\circ} 42^{\prime} \\
66^{\circ} 29^{\prime}\end{array}$ & $18-20$ & $O H(15)$ & $\begin{array}{l}O B(2) \\
O H(7)\end{array}$ & $O H(15)$ & $\begin{array}{l}17.75 \\
(13.17-32.90)\end{array}$ \\
\hline CHU, Chubut River (Los Altares); Chubut basin & $\begin{array}{l}43^{\circ} 51^{\prime} \\
68^{\circ} 48^{\prime}\end{array}$ & 18 & $O H(29)$ & $O H(11)$ & $O H(28)$ & $\begin{array}{l}8.04 \\
(5.15-11.26)\end{array}$ \\
\hline MUS, Lake Musters; Chubut basin & $\begin{array}{l}45^{\circ} 28^{\prime} \\
69^{\circ} 10^{\prime}\end{array}$ & $16-18$ & $O H(25)$ & $O H(11)$ & $O H(25)$ & $\begin{array}{l}11.68 \\
(5.70-22.94)\end{array}$ \\
\hline LBA, Lake Buenos Aires; Aysen basin (Pacific) & $\begin{array}{l}46^{\circ} 29^{\prime} \\
71^{\circ} 28^{\prime}\end{array}$ & 14 & $O H(36)$ & $O H(23)$ & $O H(36)$ & $\begin{array}{l}17.59 \\
(8.91-27.17)\end{array}$ \\
\hline PUY, Lake Pueyrredón; Baker basin (Pacific) & $\begin{array}{l}47^{\circ} 23 \\
71^{\circ} 55^{\prime}\end{array}$ & $12-14$ & $O H(29)$ & $O H(12)$ & $O H(29)$ & $\begin{array}{l}14.15 \\
(9.24-39.05)\end{array}$ \\
\hline
\end{tabular}


Genetic analysis. To assess maternal genetic identity, mitochondrial DNA (mtDNA) sequences of the cytochrome $b$ gene (cyt $b$ ) were collected from a subsample of individuals (Table 1) and two outgroup specimens (O. smitti (Lahille, 1929), a strictly marine species obtained from a coastal South Atlantic locality near Puerto Madryn, Argentina). DNA was extracted from ethanol-preserved tissues using a Promega Wizard kit (Promega Corp.). The primer (forward) GLU31 (Unmack et al., 2009) and a speciesspecific primer designed for this study (Pej15929 5'CGGCGTTCGGTTTACAAGAC-3') were used to amplify cyt $b$ by PCR. The target DNA fragment was amplified in $12 \mu \mathrm{l}$ reactions using $25 \mathrm{ng}$ of template DNA, $0.25 \mathrm{mM}$ of each primer, 0.625 units of Taq DNA polymerase, $0.1 \mathrm{mM}$ of each dNTP, $1.25 \mu \mathrm{L}$ of $10 \mathrm{X}$ reaction buffer and $1.25 \mu \mathrm{l}$ of $25 \mathrm{mM} \mathrm{MgCl} 2$. Amplification thermocycler parameters were: $94^{\circ} \mathrm{C}$ for $2 \mathrm{~min}$ followed by 35 cycles of $94^{\circ} \mathrm{C}$ for 30 $\mathrm{s}, 50.7^{\circ} \mathrm{C}$ for $45 \mathrm{~s}, 72^{\circ} \mathrm{C}$ for $60 \mathrm{~s}$, and, finally, $72^{\circ} \mathrm{C}$ for 10 min. PCR products were purified using 96-well Excelapure filter plates (Edge Biosystems). Templates were sequenced from both directions using the same primers used for PCR amplification and resolved on an Applied Biosystems 3730 XL automated sequencer (Brigham Young University DNA Sequencing Center). Raw chromatograms were assembled into contigs and edited using Sequencher version 4.8 (Gene Codes Corp.). Sequences were then aligned using MAFFT version 6 (Katoh \& Toh, 2008). Identical sequences obtained from multiple individuals were identified and collapsed to unique haplotypes using FaBOX (Villesen, 2007) before phylogenetic analysis.

The cyt $b$ alignment was partitioned by codon position and an independent model of sequence evolution was determined for each partition using the Treefinder software version 13.0.0 (Jobb, 2008). Phylogenetic relationships between unique haplotypes were estimated by Maximum Likelihood (ML) analyses using said software and 100 bootstrap pseudoreplicates to estimate support for the resulting phylogeny. In order to obtain information regarding zygotic genetic identity in Odontesthes, nuclear microsatellite markers are being developed (G. Ortí pers. obs.).

Geometric morphometric analysis. Morphometric characters were scored and analyzed to quantify anatomical differences between species.

Fifteen landmarks (Fig. 2) were digitized from 436 individuals with the TpsDig v2.10 software (Rohlf, 2006). Landmarks used were: 1, anterior tip of the premaxilla; 2 , eye center; 3 , posterior process of symplectic bone; 4 , dorsal insertion of the pectoral fin; 5, anterior insertion of the first dorsal fin; 6, anterior insertion of the second dorsal fin; 7, dorsal insertion of the caudal fin; 8, posterior end of the lateral line; 9 , ventral end of the caudal fin; 10 , anterior insertion of the anal fin; 11, anus; 12, distal tip of the pelvic fin onto fish body; 13, anterior insertion of the pelvic fin; 14, vertical tie of landmark 12 onto the lateral line; and 15 , vertical tie of landmark 10 onto the lateral line. These were chosen to include the diagnostic anatomical features for the Dyer (2006) identification key and other standard points commonly used for fish morphometrics. Landmark configurations for each specimen were aligned, rotated, translated and scaled by a Generalized Procrustes Analysis (GPA), (Rohlf \& Slice, 1990) using a consensus configuration as a reference (Rohlf and Slice, 1990; Rohlf and Marcus, 1993). The unbending command, landmarks 4,8 , and two landmarks on the lateral line (14 and 15) were used to correct body position. After the unbending process landmarks 14 and 15 were eliminated from the analysis. Partial (PW) and Relative Warps (RW) were calculated using TpsRelw v1.35 (Rohlf, 2003a). RWs allowed the visualization of mean body shape of each population by means of deformation grids relative to the consensus shape. Cluster Analysis (CA, centroid clustering and average linkage between groups) and Discriminant Analysis (DA) were performed with SPSS software employing the PW and uniform coordinates (weight matrix, Rohlf, 1996) in order to group fish on the basis of overall body shape, test differences between species and presumptive hybrids, and within species between capture sites, respectively. The percentage of individuals correctly grouped and the probability of each individual being correctly grouped were obtained from the analysis.

In order to assess the effects of size on body shape within each species, TPSRegr 1.28 (Rohlf, 2003b) and polynomial regressions between Discriminant Functions (DFs) and independent variables such as sampling sites and SL, were assayed. The degree of the polynomial was assessed on the basis of $\mathrm{R}^{2}$ and the significance of the polynomial coefficients. In order to visualize deformation grids for sampling sites where shape differences were not explained by size effect, a new set of RWs was obtained.

The effects of environmental factors on body shape were studied. Discriminant functions based on geometric morphometric analysis were used to correlate body shape with the following environmental parameters of sampling sites: mean summer air temperature $\left({ }^{\circ} \mathrm{C}\right.$, as an estimation of summer surface water temperature, Livingstone \& Lotter, 1998), latitude $\left({ }^{\circ} \mathrm{S}\right)$, longitude $\left({ }^{\circ} \mathrm{W}\right)$, area of the lake or reservoir $\left(\mathrm{km}^{2}\right)$, perimeter $(\mathrm{km})$, perimeter/area ratio $\left(P_{\mathrm{AR}}\right)$, coastline development $\left(L_{\mathrm{CD}}\right.$, Wetzel, 1981), mean depth (m), altitude (m a.s.l.), conductivity $\left(\mu \mathrm{S} . \mathrm{cm}^{-1}\right)$, chlorophyll a $\left(\mathrm{mg} \cdot \mathrm{m}^{-3}\right)$, Total Phosphorous (TP, mg.m $\left.{ }^{-3}\right)$, Total Nitrogen (TN, mg. $\mathrm{m}^{-3}$ ), and TN:TP ratio. Most of these data came from the ARLARE database (Quirós et al., 1988; Quirós, 1997) and other publications (IARHINCYTH, 1995; Colautti et al., 1998; Díaz et al., 2000; Modenutti et al., 2000). Altitude, area, and perimeter were obtained from Google Earth (www.earth.google.com) and processed with Image Pro Plus 6.0 software. Correlation and stepwise regression analyses were used to select independent variables (using a Bonferroni correction for multiple comparisons). 


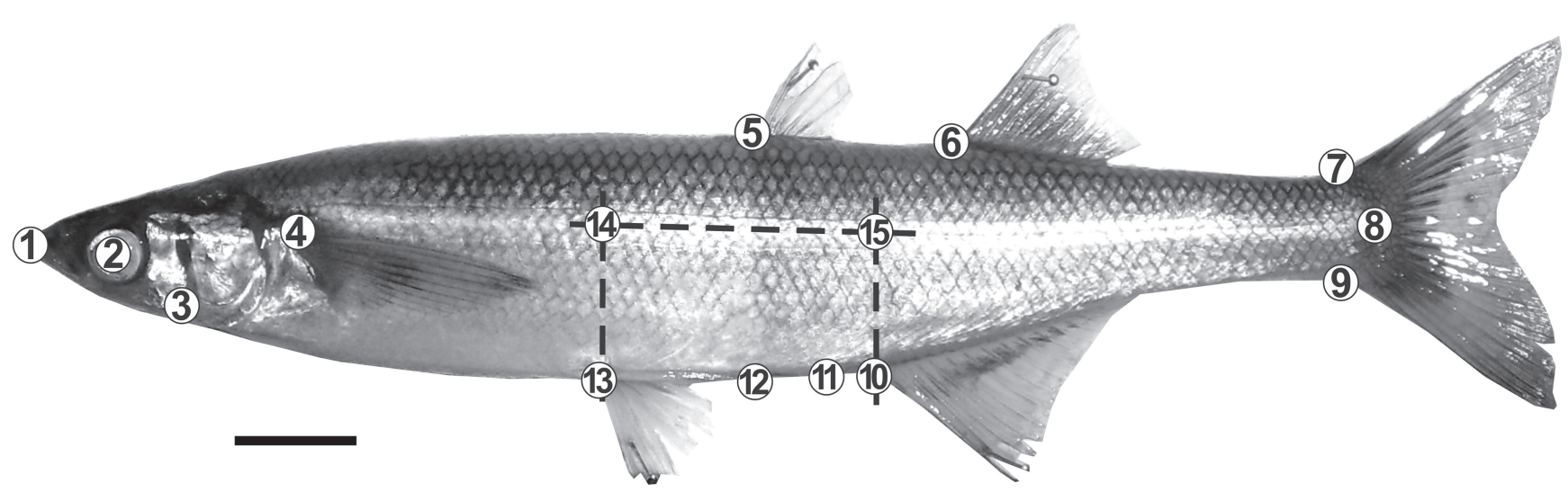

Fig. 2. Landmarks used in geometrics morphometrics analysis: 1, anterior tip of the premaxilla; 2, eye center; 3, posterior process of symplectic bone; 4 , dorsal insertion of the pectoral fin; 5 , anterior insertion of the first dorsal fin; 6 , anterior insertion of the second dorsal fin; 7, dorsal insertion of the caudal fin; 8, posterior end of the lateral line; 9, ventral end of the caudal fin; 10 , anterior insertion of the anal fin; 11, anus; 12 , distal tip of the pelvic fin onto fish body; 13 , anterior insertion of the pelvic fin; 14 , vertical tie of landmark 12 onto the lateral line; 15, vertical tie of landmark 10 onto the lateral line. Black line scale: $2 \mathrm{~cm}$.

\section{Results}

Species identification. The identification key based on adult morphological and meristic characters (most importantly; size of dorsal scales and position of the first dorsal fin in relation to the position of the pelvic fin and anus) provided unambiguous diagnosis for most samples (Table 1). However, some fish from PELE exhibited inconsistencies when checked against key characters and identification for a group of individuals with mixed specific characters (Table 2) was problematic. These fish exhibited dorsal fin position as expected for $O$. bonariensis, dorsal scale size (number of rows) typical of $O$. hatcheri, and mitochondrial DNA corresponding to $O$. bonariensis $(\mathrm{N}=$ $5)$ or to O. hatcheri $(\mathrm{N}=10$, Table 2, Fig. 3).

Cytochrome $b$ sequences $(1,125 \mathrm{bp})$ were obtained for a total of 151 specimens, including the two outgroup individuals $(O$. smitti, collected from a coastal marine location near Puerto Madryn). Among the 151 sequences, 72 unique haplotypes were identified and used for phylogenetic analysis (GenBank Accessions KJ499111-KJ499182). The most frequent haplotype (haplotype 5) was shared by a total of 50 individuals collected from several localities (see Fig. 1), ranging from the Salado/Colorado basin (localities NIHL, URRE), to the Chubut basin (AME, CHU, MUS), and the Pacific-flowing Baker basin (PUY, LBA). This common haplotype, widely distributed throughout the native range of $O$. hatcheri, suggests that either range expansion or an extensive gene flow between all these currently separated basins must have occurred in the recent past. Other examples of such widespread distribution of shared haplotypes include fish collected from URRE and AME (Salado/Colorado and Chubut basins, respectively). Other unique haplotypes were shared by individuals obtained from the same locality (e.g., by two individuals from CDP, by nine individuals from EPU, by two individuals from MUS, and by several individuals from PELE and RIV). Two haplotypes were shared by individuals obtained from different localities within the Rio Negro basin (by individuals from MITO and PELE). It is important to note that all these common alleles were shared by individuals assigned to the same species according to morphological criteria; common alleles were never shared between species.

Phylogenetic analysis of the 72 unique haplotypes was conducted to test for reciprocal monophyly of alleles for the three nominal species included in the study. A partitioned maximum likelihood (ML) approach was implemented using three partitions, optimizing an independent model for each codon position in the alignment. The "propose model" routine in Treefinder based on the AICc recommended $\mathrm{TN}+\mathrm{G}$ models for first and second codon position sites and the $\mathrm{HKY}+\mathrm{G}$ model for third codon positions of the cyt $b$ gene. Parameters for these models were optimized independently for each data partition and three replicate searches were conducted. The resulting phylogeny is shown in Fig. 3. The $O$. hatcheri and $O$. bonariensis haplotypes formed strongly supported (100 percent bootstrap values) reciprocally monophyletic groups, with $7 \%$ average sequence difference between groups (uncorrected distance). In contrast, sequence differences within each group were smaller than $1 \%$ in every case. Average differences from the outgroup sequences were $3 \%$ for $O$. hatcheri and $6 \%$ for $O$. bonariensis. Genetic identity based on the cyt $b$ sequences is robust to intraspecific variation and provides an unambiguous signature for comparison with morphological data.

A total of 436 fish were digitized and used for morphometric analyses (Table 1, sample size for each locality ranged from 5 to 36). Considering all individuals, the RW1 and RW2 explained $68.2 \%$ of total variation (Table 3). Main differences involved relative anteroposterior position of dorsal and pelvic fins, body height and head length (Fig. 4). Cluster analysis applied to all the individuals showed three main groups; $O$. bonariensis, $O$. 
hatcheri, and presumptive hybrids. In effect, Discriminant Analysis of the three groups showed two significant functions: pairwise significant differences $(P<0.0001)$ and $89 \%$ of cases grouped correctly. Separation of the two species was clear for DF1. The difference between $O$. hatcheri and presumptive hybrids was observed using the residual of DF2 versus SL (Fig. 5, Table 4). Discriminant Analysis also provided the probability of membership to the original group. In several sites, an appreciable number of taxonomically identified $O$. hatcheri individuals had low probabilities of being $O$. hatcheri. This was not observed for O. bonariensis (Fig. 6).

Table 2. Meristic and morphological characters applied to the identification (following Dyer, 2006) of 45 individuals from Lake Pellegrini. Results from mtDNA analysis are compared with identification based on taxonomic key: origin of first dorsal fin over posterior half of pelvic fin (O. hatcheri ) or anterior to anus and posterior to pelvic fin (O. bonariensis), number of dorsal scale rows between lateral lines $>12$ (O. hatcheri) or $<11(O$. bonariensis); number of gill rakes on the lower arm of first branchial arch, $21-27$ (O. hatcheri) or $>30$ (32-38) (O. bonariensis); upper jaw prognathous $(O$. hatcheri) or lower jaw prognathous in large specimens (O. bonariensis). N: number of specimens. In bold, the presumptive hybrids individuals identified on meristic and morphological characters, those are highlighted with * in Fig. 3).

\begin{tabular}{|c|c|c|c|c|c|c|}
\hline \multicolumn{2}{|c|}{ Origin of first dorsal fin } & \multirow{2}{*}{$\begin{array}{l}\text { Number of dorsal } \\
\text { scale rows between } \\
\text { lateral lines }\end{array}$} & \multirow{2}{*}{$\begin{array}{l}\text { Number of gill rakes } \\
\text { on the lower arm of } \\
\text { first branchial arch }\end{array}$} & \multirow{2}{*}{$\begin{array}{l}\text { Jaw } \\
\text { prognathism }\end{array}$} & \multirow{2}{*}{$\begin{array}{l}\text { Species based } \\
\text { on key }(\mathrm{N})\end{array}$} & \multirow{2}{*}{$\begin{array}{l}\text { Species based } \\
\text { on mtDNA (N) }\end{array}$} \\
\hline $\begin{array}{l}\text { Over posterior } \\
\text { half of pelvic fin }\end{array}$ & $\begin{array}{l}\text { Anterior to anus and } \\
\text { posterior to pelvic fin }\end{array}$ & & & & & \\
\hline & $\mathrm{X}$ & 13 & 30 & upper & hybrid? & O. bonariensis \\
\hline & $\mathrm{X}$ & 12 & 29 & lower & hybrid? & - \\
\hline & $\mathrm{X}$ & 12 & 31 & no & hybrid? & O. bonariensis \\
\hline & $\mathrm{X}$ & 13 & 31 & upper & hybrid? & O. bonariensis \\
\hline & $\mathrm{X}$ & 12 & 28 & lower & hybrid? & O. bonariensis \\
\hline & $\mathrm{X}$ & 13 & 30 & lower & hybrid? & O. bonariensis \\
\hline $\mathrm{X}$ & & 15 & 22 & upper & O. hatcheri & - \\
\hline $\mathrm{X}$ & & 15 & 23 & no & O. hatcheri & O. hatcheri \\
\hline $\mathrm{X}$ & & 15 & 23 & upper & O. hatcheri (2) & O. hatcheri \\
\hline $\mathrm{X}$ & & 15 & 24 & no & O. hatcheri & O. hatcheri \\
\hline $\mathrm{X}$ & & 15 & 24 & upper & O. hatcheri (4) & - \\
\hline $\mathrm{X}$ & & 15 & 25 & upper & O. hatcheri (2) & O. hatcheri (2) \\
\hline $\mathrm{X}$ & & 16 & 24 & upper & O. hatcheri (2) & O. hatcheri \\
\hline $\mathrm{X}$ & & 16 & 25 & upper & O. hatcheri (4) & O. hatcheri (2) \\
\hline $\mathrm{X}$ & & 16 & 26 & upper & O. hatcheri (2) & O. hatcheri \\
\hline & $\mathrm{X}$ & 13 & 27 & no & hybrid? & O. hatcheri \\
\hline & $\mathrm{X}$ & 14 & 24 & upper & hybrid? & - \\
\hline & $\mathrm{X}$ & 15 & 23 & upper & hybrid? (3) & O. hatcheri (2) \\
\hline & $\mathrm{X}$ & 15 & 25 & no & hybrid? & O. hatcheri \\
\hline & $\mathrm{X}$ & 16 & 24 & upper & hybrid? & O. hatcheri \\
\hline & $\mathrm{X}$ & 16 & 25 & upper & hybrid? & O. hatcheri \\
\hline & $\mathrm{X}$ & 15 & 22 & upper & hybrid? & O. hatcheri \\
\hline & $\mathrm{X}$ & 15 & 23 & upper & hybrid? (2) & - \\
\hline & $\mathrm{X}$ & 15 & 24 & upper & hybrid? & O. hatcheri \\
\hline & $\mathrm{X}$ & 15 & 25 & upper & hybrid? (2) & - \\
\hline & $X$ & 16 & 22 & upper & hybrid? & O. hatcheri \\
\hline & $\mathrm{X}$ & 16 & 24 & upper & hybrid? (2) & - \\
\hline & $\mathrm{X}$ & 16 & 25 & upper & hybrid? & - \\
\hline & $\mathrm{X}$ & 17 & 24 & upper & hybrid? (2) & O. hatcheri \\
\hline
\end{tabular}




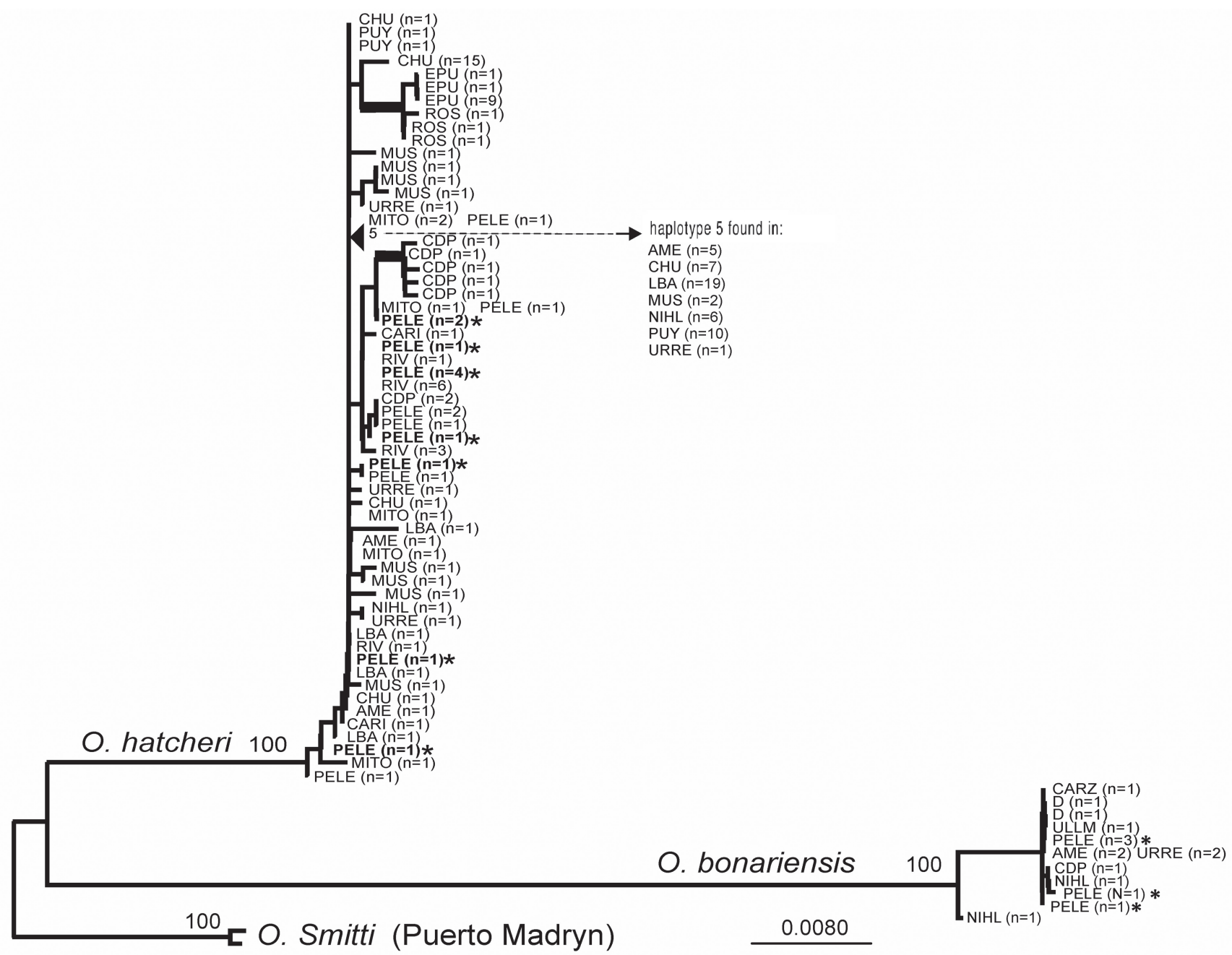

Fig. 3. Maximum likelihood phylogeny for 72 unique haplotypes obtained from $O$. hatcheri, $O$. bonariensis, and $O$. smitti. Haplotype labels indicate their sampling locality (as explained in Fig. 1 and Table 1) and the number of individuals (in parentheses). Several common haplotypes were recovered from several individuals from the same or different localities (most significantly haplotype 5). Monophyly of haplotypes from each species is supported by $100 \%$ bootstrap values, and two groups of $O$. hatcheri haplotypes (from EPU and CDP, indicated by heavier lines) also received strong bootstrap support. All other nodes were weakly supported by bootstrap analyses. *: presumptive hybrids individuals identified on meristic and morphological characters (Table 2).

Table 3. Interspecific and intraspecific morphological variation of Odontesthes species. Variance explained (\%) by first and second RW is indicated. N: number of specimens.

\begin{tabular}{llll}
\hline Data subsets & $\mathrm{N}$ & \multicolumn{2}{l}{ Variance explained (\%) } \\
\hline & & $\mathrm{RW} 1$ & $\mathrm{RW} 2$ \\
\hline all individuals & 436 & 48.30 & 19.92 \\
O. bonariensis & 100 & 46.68 & 19.69 \\
O. bonariensis from CARZ and D & 64 & 45.69 & 13.88 \\
O. hatcheri & 315 & 44.81 & 16.21 \\
O. hatcheri from PUY, NIHL, CDP, and PDA & 79 & 42.34 & 19.35 \\
\hline
\end{tabular}

Variation within species. RW1 and RW2 explain a great proportion of the total variation of $O$. hatcheri. Similar results were obtained for $O$. bonariensis (Table 3). There were significant relationships between body shape and fish size for each sampling locality. These relationships were significantly different between sites for both $O$. bonariensis and $O$. hatcheri (Tpsregr, $n=100, P<0.001$; Tpsregr, $n=315, P<0.001$, respectively).

Discriminant Analysis for $O$. bonariensis populations produced 4 significant DFs, identifying 5 groups. DF1 and DF2 depended significantly on size (Table 4). Notwithstanding this dependence, DF1 revealed body shape differences between CARZ and D (Fig. 7). In effect, it can be seen that 'pejerrey' of CARZ had slightly longer caudal peduncles than D individuals (Fig. 7). Another noticeable trend is that DF1 $(\mathrm{r}=0.346, n=100, P=0.005)$ and DF2 ( $\mathrm{r}=-0.431, n=100, P<0.001)$ residuals (from regression with SL) showed a significant correlation with the Condition Factor. 


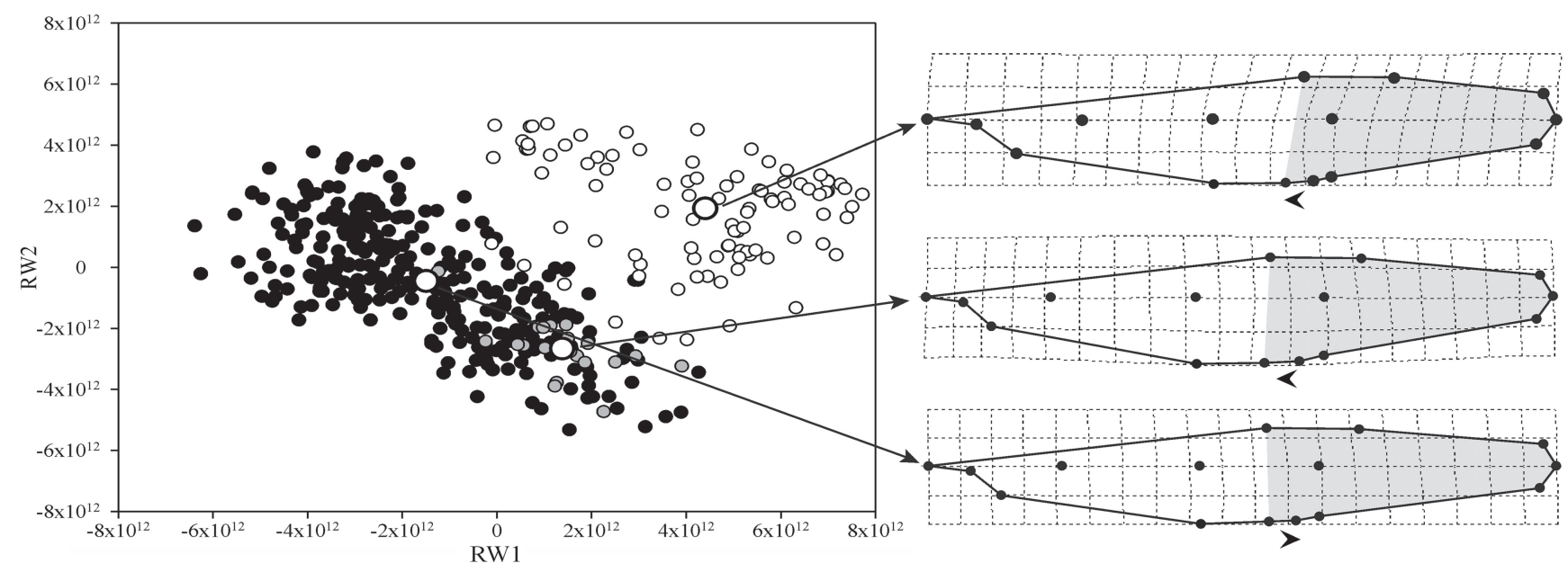

Fig. 4. Geometric Morphometric Analysis applied to Odontesthes individuals. RW2 versus RW1 and deformation grids (tied to group means) for Odontesthes bonariensis (white circle), O. hatcheri (black circle) and presumptive hybrids (gray circle). Arrowheads indicate displacement of landmarks relative to consensus. Shaded area shows relative position of landmarks 5 (anterior insertion of the first dorsal fin) and 12 (distal tip of the pelvic fin onto fish body).
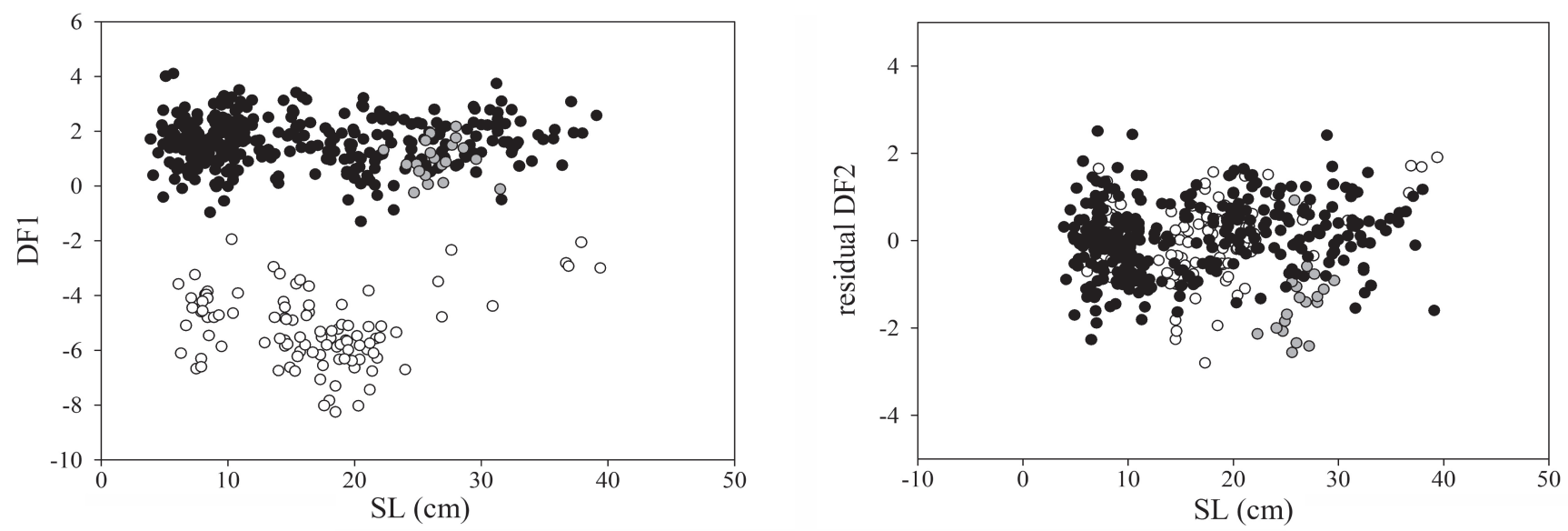

Fig. 5. Morphometric differences between species. DF1 and residual DF2 (of the regression of DF2 versus Standard length) vs. Standard length (SL). Odontesthes bonariensis (white circle), O. hatcheri (black circle), and presumptive hybrids (gray circle).

Table 4. Discriminant Analyses results for two species of Odontesthes.

\begin{tabular}{|c|c|c|c|c|c|c|c|c|}
\hline Groups & $\mathrm{N}$ & $\begin{array}{l}\text { Cases correctly } \\
\text { grouped }(\%)\end{array}$ & $\begin{array}{l}\text { Discriminant } \\
\text { Function }\end{array}$ & $\begin{array}{l}\text { Variance } \\
\text { explained (\%) }\end{array}$ & $\begin{array}{l}\text { Canonical } \\
\text { correlation }\end{array}$ & Eigenvalues & $\begin{array}{l}\text { Wilks' Lambda } \\
\text { signification }\end{array}$ & $\begin{array}{l}\text { Regression with size } \\
\text { signification }\end{array}$ \\
\hline $\begin{array}{l}\text { O. bonariensis sampling } \\
\text { sites ( } 5 \text { groups) }\end{array}$ & 100 & 100 & $\begin{array}{l}1 \\
2 \\
3 \\
4 \\
\end{array}$ & $\begin{array}{l}56.2 \\
33.8 \\
6.9 \\
3.1 \\
\end{array}$ & $\begin{array}{l}0.953 \\
0.925 \\
0.741 \\
0.595\end{array}$ & $\begin{array}{l}9,894 \\
5.954 \\
1.216 \\
0.549\end{array}$ & $\begin{array}{l}0.000 \\
0.000 \\
0.000 \\
0.007\end{array}$ & $\begin{array}{c}0.001 \\
0.002 \\
>0.05 \\
>0.05\end{array}$ \\
\hline $\begin{array}{l}\text { O. hatcheri sampling } \\
\text { sites (12 groups) }\end{array}$ & 315 & 90.8 & $\begin{array}{l}1 \\
2 \\
3 \\
4 \\
5 \\
6 \\
7 \\
8 \\
9 \\
10 \\
11\end{array}$ & $\begin{array}{l}47.6 \\
14.6 \\
1.1 \\
6.7 \\
5.7 \\
4.4 \\
3.3 \\
2.7 \\
1.6 \\
1.2 \\
0.6\end{array}$ & $\begin{array}{l}0.944 \\
0.845 \\
0.809 \\
0.731 \\
0.701 \\
0.655 \\
0.602 \\
0.565 \\
0.460 \\
0.406 \\
0.314\end{array}$ & $\begin{array}{l}8.113 \\
2.491 \\
1.899 \\
1.146 \\
0.966 \\
0.752 \\
0.569 \\
0.469 \\
0.269 \\
0.197 \\
0.110\end{array}$ & $\begin{array}{l}0.000 \\
0.000 \\
0.000 \\
0.000 \\
0.000 \\
0.000 \\
0.000 \\
0.000 \\
0.000 \\
0.000 \\
0.006\end{array}$ & $\begin{array}{l}0.000 \\
>0.05 \\
>0.05 \\
>0.05 \\
>0.05 \\
>0.05 \\
>0.05 \\
>0.05 \\
>0.05 \\
>0.05 \\
>0.05\end{array}$ \\
\hline
\end{tabular}




\section{O. hatcheri}

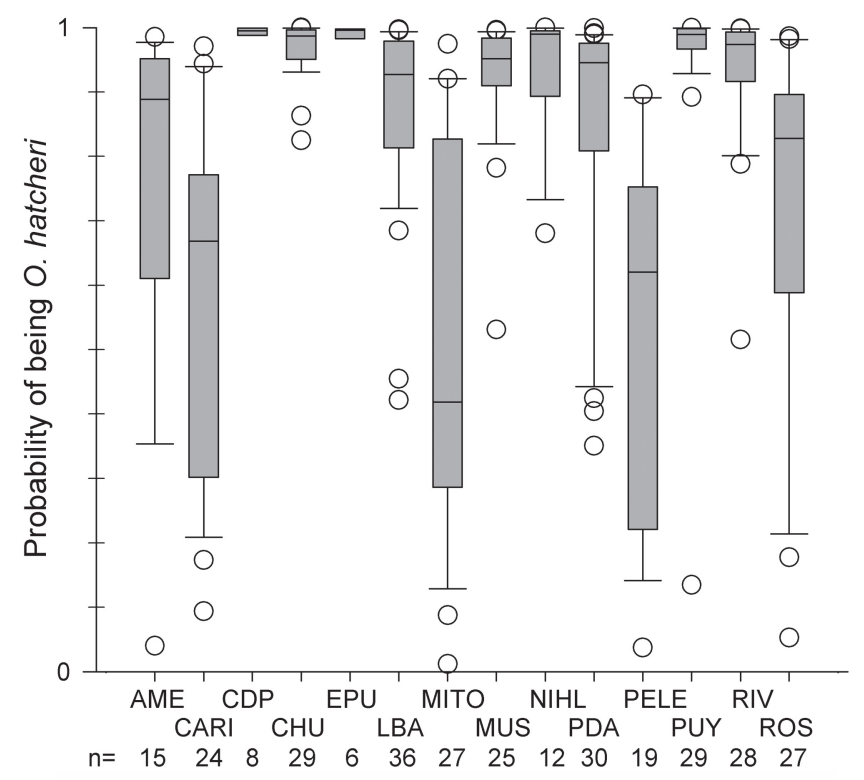

O. bonariensis

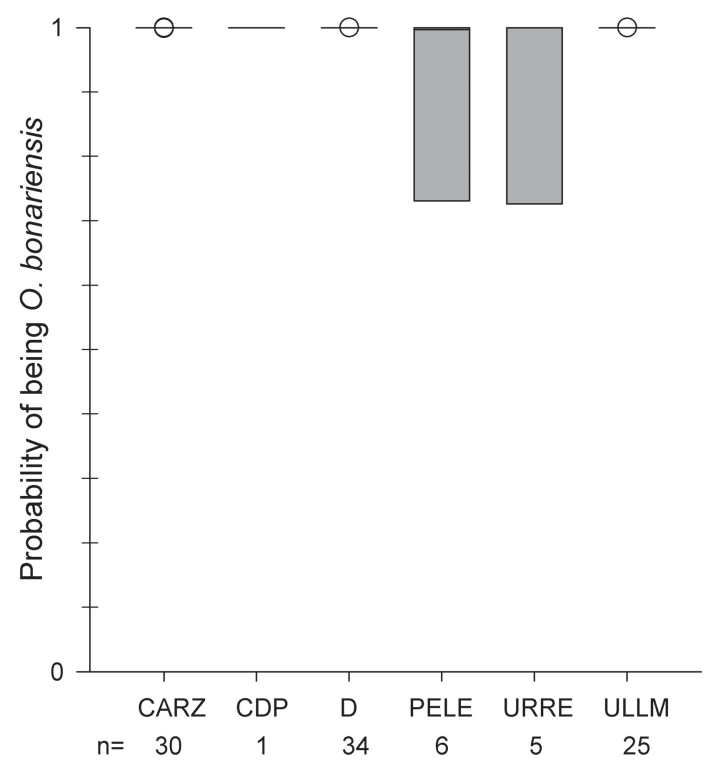

Fig. 6. Probability for taxonomically identified Odontesthes hatcheri individuals of being $O$. hatcheri (left) and probability of taxonomically identified $O$. bonariensis individuals of being $O$. bonariensis (right). Number of fish, median, quartiles, and data outside 10 and $90^{\text {th }}$ percentile are indicated. Water bodies are named as in Fig. 1.

Discriminant Analysis for O. hatcheri revealed 11 significant DFs for the 13 sampling sites (Table 4). DF1 showed significant dependence on size (Fig. 7), but this was not observed for the other DFs. The DF3 versus DF2 graph (Fig. 8) showed major differences between body shapes corresponding to PUY (the type locality of $O$. hatcheri, Ringuelet et al., 1967) and the PDA, CDP and NIHL reservoirs. The deformation grids showed that CDP individuals had lower body, and the landmarks related to anus, pelvic and anal fins (10,11 and 12) in an anterior position, in contrast to that observed in individuals from PUY (Fig. 8, Table 3). DF1 (residuals of the regression of DF1 versus $\mathrm{SL}$ ), DF2, and DF4 showed a significant correlation $(r=-0.265, n=315, P<0.001 ; r=0.197, n=315, P<0.001$ and $r=0.192, n=315, P=0.002$, respectively) with Condition Factor. Although the number of significant DFs allows discrimination of all the sampling sites, the differences that could be visualized were extremely low (Fig. 8).

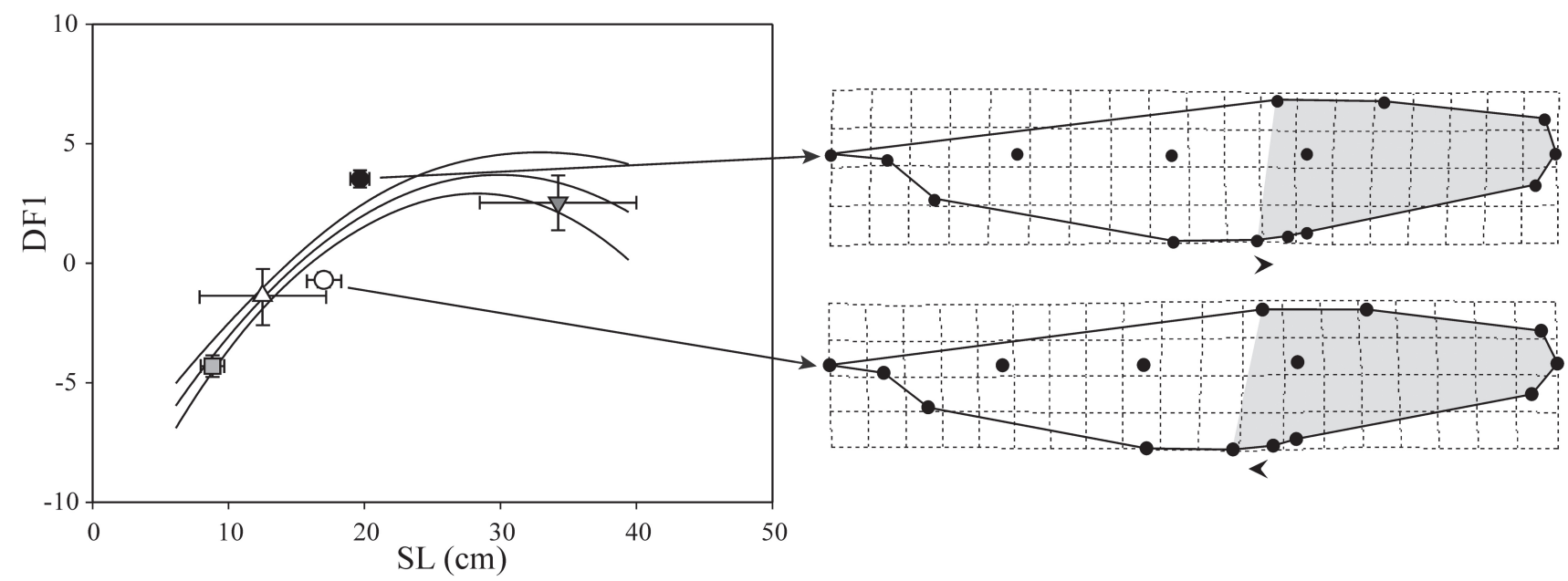

Fig. 7. Geometric Morphometric Analysis applied to Odontesthes bonariensis individuals. Left: plot of DF1 vs. Standard length (SL), showing quadratic fit with $95 \%$ confidence interval $(\mathrm{N}=100)$ and means and $95 \%$ confidence intervals by sampling sites (locality labels as in Fig. 1) ULLM (gray square), CARZ (white circle), D (black square), URRE (white triangle), PELE (gray triangle). Right: Deformation grids correspond to a relative warps analysis (see Table 3) involving only CARZ and D. Arrows indicate displacement of landmarks relative to consensus. Shaded area remarks relative position of landmarks 5 (anterior insertion of the first dorsal fin) and 12 (distal tip of the pelvic fin onto fish body). 


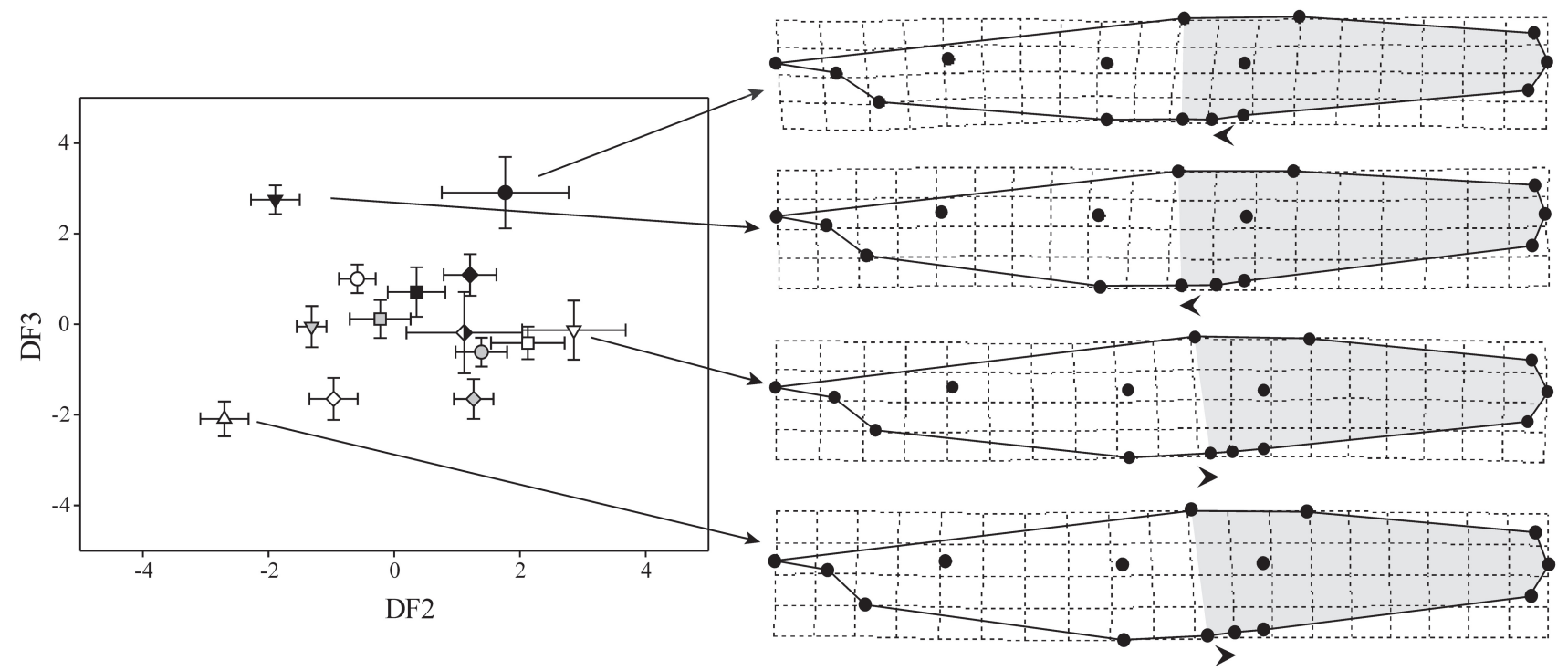

Fig. 8. Geometric Morphometric Analysis applied to O. hatcheri individuals. Left: plot of DF3 vs. DF2 showing means and 95\% confidence intervals by sampling sites (locality labels as in Fig. 1) NIHL (white triangle), CDP (black circle), 7: PELE (gray square), PDA (black triangle), MITO (black diamond), CARI (white square), EPU (black and white diamond), RIV (gray circle), ROS (white diamond), AME (black square), CHU (gray diamond), MUS (gray triangle), LBA (white circle), and PUY (white triangle). Right: deformation grids correspond to a relative warps analysis involving only CDP, PDA, and NIHL and PUY. Arrowheads indicate displacement of landmarks relative to consensus. Shaded area remarks relative position of landmarks 5 (anterior insertion of the first dorsal fin) and 12 (distal tip of the pelvic fin onto fish body).

Body shape and environmental parameters. Regarding geographic, physical and chemical parameters of lakes and reservoirs, significant regressions were found between DF1 residuals of $O$. hatcheri and phosphorous concentration (TP, regression, $n=14, P<0.005$ ), and altitude (regression, $n=14, P<0.001)$.

\section{Discussion}

Species boundaries between $O$. hatcheri and $O$. bonariensis are clearly revealed by morphological and genetic traits, in agreement with current taxonomy. Although morphological differences between these two species were small and mainly related to the position of dorsal fins, the degree of genetic variation in the cytb gene $(7 \%)$ is significant. Genetic distances estimated from mtDNA have been used in many instances to validate vertebrate species (Johns \& Avise, 1998), indicating that more than $90 \%$ of vertebrate sister species exhibit a cyt $b$ divergence of at least $2 \%$. At intra-specific level, variation between $O$. hatcheri populations observed in this study was low (less than 1\%), with no clear distinction of haplogroups or geographic orientation. A common cytb haplotype (haplotype 5, Fig. 3) was widely distributed, encompassing most of the species' range.

In just one sampling locality (PELE) a group of individuals displayed intermediate morphology, as already reported (Dyer, 2006). In agreement with Crichigno et al. (2013), our current analyses showed that intermediate individuals fall closer to the morphospace of $O$. hatcheri
(Fig. 5) but DA was able to differentiate between them and $O$. hatcheri. In addition to PELE, four reservoirs and one lake in the distribution area of $O$. hatcheri have been reported to contain $O$. bonariensis (Liotta, 2006). The Ezequiel Ramos Mexía reservoir, three reservoirs used for this study (NIHL, CDP, and AME), and one lake (URRE) included both species, but did not yield intermediate forms as in PELE. Only the last-mentioned has an artisanal fishery.

The distribution of $\mathrm{O}$. bonariensis in the colder lakes and reservoirs of the Andean Region could be limited by temperature-dependent factors (Strüssmann et al., 2010). These species show a very different degree of temperaturedependent sex determination (TSD; Strüssmann et al., 1997b). Odontesthes bonariensis individuals exposed to a temperature of approximately $17^{\circ} \mathrm{C}$ from hatching to juvenile stage all became female (Strüssmann et al., 1997b). In temperate regions, mean air and water temperatures are likely to correspond most closely in midsummer (Livingstone \& Lotter, 1998). Odontesthes hatcheri breed in late spring to early summer (Cussac et al., 1992) and $O$. bonariensis in spring and autumn (Ringuelet, 1943). As Cussac et al. (2009) have already suggested, the results of this survey (Ameghino reservoir being the southernmost locality) confirm that $O$. bonariensis is absent when mean summer air temperatures are lower than $20^{\circ} \mathrm{C}$ (www.smn. gov.ar; Liotta, 2006, Table 1). According to the above discussion, $O$. bonariensis populations in colder lakes towards the south of the distribution area (higher latitude) are expected to have a higher proportion of females than 
males. Therefore, if hybridization occurs in these lakes, hybrids are likely to carry $O$. bonariensis mtDNA. As Ringuelet (1943) noted, however, artificial fertilization is a common practice when fishermen capture ripe 'pejerrey', releasing fertilized eggs back to the lake. This practice, the probable natural segregation of reproductive habitats, and artificial bias in the capturing carried out by the artisan fishery could be explanations as to why Lake Pellegrini is the only site where conspicuous intermediate individuals were reported and why their cyt $b$ haplotype identification is unexpected.

Several methods have been proposed in the literature for the identification of fish hybrids. External morphology is unreliable when used as the sole means of identification in such analyses, particularly for hybrid individuals beyond the F1 generation (Hashimoto et al., 2012). Simple PCR-based techniques that can differentiate F1 and postF1 hybrids from wild types using different microsatellite markers have been developed for several species (Hashimoto et al., 2012; Allu et al., 2014; Hasselman et al., 2014). At present, nuclear microsatellite markers are being developed in order to estimate the probability of individuals belonging to distinct hybrids or purebred Odontesthes categories (G. Ortí pers. obs.).

Both $O$. hatcheri and $O$. bonariensis are extremely susceptible to stress, frequently dying due to handling (Tsuzuki et al., 2000a,b). In consequence, brood stocks were never established in Argentina before 2001, when Somoza et al. (2008) implemented spontaneous spawning of $O$. bonariensis in captivity. Thus, the southernmost hatchery (Piscicultura Río Limay) participating since 1930 in 'pejerrey' stocking programs throughout the Andean Cuyan and Patagonian Provinces (Crichigno et al., 2013) always stocked fish obtained from adults caught in neighboring sites, e.g. Lake Pellegrini. In consequence, and in agreement with the results of Crichigno et al. (2013), even lakes and reservoirs with water temperature too low for $O$. bonariensis could have received lowtemperature-resistant hybrid and / or introgressed individuals, resulting in $O$. hatcheri populations with high morphological variation. There, taxonomically assigned $O$. hatcheri individuals could have a low probability of being classified as $O$. hatcher $i$ in geometric morphometric analysis (Fig. 6).

Intraspecific variation in morphology within each species suggests, though in a slightly different way for each one, that morphological variation mainly affects body height, caudal peduncle size, and the relationship between body height and the Condition Factor. In particular, morphological variation within $O$. hatcheri involves body height and the relative positions of the anus, pelvic and anal fins. In agreement with Aigo et al. (2008), who positively relate abundance of $O$. hatcher $i$ to the area of the lake, and the dependence of cephalic shape of $O$. hatcheri on coastline development (Crichigno et al., 2013), significant relationships between DFs and independent variables affecting quality and quantity of planktonic food availability (TP and altitude) were observed. Part of this variation could be ascribed to phenotypic plasticity (Crichigno et al., 2012).

In conclusion, present results increase biological knowledge of these species and provide new insights into the conservation of $O$. hatcheri populations. The poor diversity of Patagonian fish fauna successfully overcame a long history of environmental changes in Patagonia (Cussac et al., 2009) and O. hatcheri was naturally distributed across more than 18 latitudinal degrees. However, the human practice of stocking fish provoked a dispersal of $O$. bonariensis in the distributional range of $O$. hatcheri. The native species is now absent and replaced by $O$. bonariensis in the north of their original distributional range (Table 1) and the ability of both species to hybridize could have created a hybrid zone.

Current taxonomy was clearly confirmed by morphological and genetic traits. Morphometric analyses can effectively discriminate between the species and their putative hybrids, in spite of the very small morphological differences, even when morphological variation includes the possible effects of genetic introgression, environmental dependence, and phenotypic plasticity (Crichigno et al., 2012).

Previous (Crichigno et al., 2013) and present results suggest the introgression of $O$. bonariensis into several $O$. hatcheri populations. Introgression in tilapia (Deines et al., 2014) and cyprinid species (Deinhardt, 2013; Meraner et al., 2013) have threatened biodiversity, signalizing that biological invasions, non-native introductions, and introgressive hybridization may have a negative impact on the genetic resources available for aquaculture and fisheries, being major drivers for the decline of native freshwater fishes. Managers should take these risks into account when considering further exotic introductions into regions where non-native fishes have not yet become established.

\section{Acknowledgments}

We thank Sonia Crichigno for her contribution to the analysis and laboratory work, Gustavo Somoza for samples from Lake San Lorenzo, and Feliciano Gómez for samples from Lake Pellegrini. We would like to acknowledge the following institutions for grants supporting the present project: Universidad Nacional del Comahue (04B147), CONICET (PIP 112-200801-00282), and FONCYT (PICT 2005-35241) of Argentina, and the NSF-PIRE award (OISE 0530267, USA) for support of collaborative research on Patagonian Biodiversity given to the following institutions (listed alphabetically): Brigham Young University, Centro Nacional Patagónico, Dalhousie University, Darwinion Botanical Institute, Universidad Austral de Chile, Universidad Nacional del Comahue, Universidad de Concepción, and University of Nebraska. 


\section{References}

Aigo, J. C., V. E. Cussac, S. Peris, S. Ortubay, S. E. Gómez, H. L. López, M. Gross, J. P. Barriga \& M.A. Battini. 2008. Distribution of introduced and native fish in Patagonia (Argentina): patterns and changes in fish assemblages. Reviews in Fish Biology and Fisheries, 18: 387-408.

Allu, P. K. R., B. Chakraborty, M. Das, N. R. Mahapatra \& S. Ghosh. 2014. PCR-based segregation of one hybrid variety of Labeo rohita and Catla catla from their wild-types. Aquaculture International, 22: 775-782.

Baigún, C. \& R. Ferriz. 2003. Distribution patterns of native freshwater fishes in Patagonia (Argentina). Organisms, Diversity and Evolution, 3: 151-159.

Bart Jr., H. L., M. D. Clements, R. E. Blanton, K. R. Piller \& D.L. Hurley. 2010. Discordant molecular and morphological evolution in buffalo fishes (Actinopterygii: Catostomidae). Molecular Phylogenetics and Evolution, 56: 808-820.

Colautti, D., M. Remes Lenicov, N. Gómez \& C. Claps. 1998. Mortandad de peces en el arroyo de San Miguel (partido de Pila, Provincia de Buenos Aires). Gayana Zoologica, 62: 191-197.

Crespin L. \& P. Berrebi. 1999. Asymmetrical introgression in a freshwater fish hybrid zone as revealed by a morphological index of hybridization. Biological Journal of the Linnean Society, 67: 57-72.

Crichigno, S. A., C. Conte-Grand, M. Battini \& V. Cussac. 2013. Cephalic morphological variation in freshwater silversides Odontesthes hatcheri and Odontesthes bonariensis in Patagonia: introgression and ecological relationships. Journal of Fish Biology, 83: 542-559.

Crichigno, S. A., M. A. Battini \& V. E. Cussac. 2012. Early morphological variation and induction of phenotypic plasticity in Patagonian pejerrey. Neotropical Ichthyology, 10: 341-348.

Cussac, V. E., D. A. Fernández, S. E. Gómez \& H. L. López. 2009. Fishes of southern South America: a story driven by temperature. Fish Physiology and Biochemistry, 35: 29-42.

Cussac, V. E., P. M. Cervellini \& M. A. Battini. 1992. Intralacustrine movements of Galaxias maculatus (Galaxiidae) and Odontesthes microlepidotus (Atherinidae) during their early life history. Environmental Biology of Fishes, 35: 141-148.

Deines, A. M., I. Bbole, C. Katongo, J. L. Feder \& D. M. Lodge. 2014. Hybridisation between native Oreochromis species and introduced Nile tilapia $O$. niloticus in the Kafue River, Zambia. African Journal of Aquatic Science, 39: 23-34.

Deinhardt, M. 2013. The invasive potential of Prussian carp in Finland under the light of a novel semi-clonal reproductive mechanism. Unpublished Master Science Thesis, University of Jyväskylä, Jyväskylä.73p.

Díaz, M., F. Pedrozo \& N. Baccalá. 2000. Summer classification of Southern Hemisphere temperate lakes (Patagonia, Argentina). Lakes and Reservoirs: Research and Management, 5: 213-229.

Dyer, B. S. 2000. Systematic review and biogeography of the freshwater fishes of Chile. Estudios Oceanológicos, 19: 99127.

Dyer, B. S. 2006. Symposium: Biology and culture of silversides (pejerreyes). Systematic revision of the South American silversides (Teleostei, Atheriniformes). Biocell, 30: 69-88.

Gómez, S. E. \& R. A. Ferriz. 2001. Algunos aspectos de la ecofisiología del pejerrey. Pp. 45-52. In: Grosman, F. (Ed.). Fundamentos Biológicos, Económicos y Sociales para una Correcta Gestión del Recurso Pejerrey. Buenos Aires, Astyanax.
Gómez, S. E., R. C. Menni, J. Gonzalez Naya \& L. Ramirez. 2007. The physical chemical habitat of the Buenos Aires pejerrey, Odontesthes bonariensis (Teleostei, Atherinopsidae), with a proposal of a water quality index. Environmental Biology of Fishes, 78: 161-171.

Hashimoto, D. T., J. A. Senhorini, F. Foresti \& F. Porto-Foresti. 2012. Interspecific fish hybrids in Brazil: management of genetic resources for sustainable use. Reviews in Aquaculture, 4: 1-11.

Hasselman, D. J., E. E. Argo, M. C. McBride, P. Bentzen, T. F. Schultz, A. A. Perez-Umphrey \& E. P. Palkovacs. 2014. Human disturbance causes the formation of a hybrid swarm between two naturally sympatric fish species. Molecular Ecology, 23: 1137-1152.

IARH-INCYTH. 1995. Catálogo de los lagos y embalses de la Argentina. Proyecto Catálogo Nacional de Lagos y Lagunas Argentinas y su Medio Ambiente. Buenos Aires: Ministerio de Economía y Obras Servicios Públicos Secretaría de Obras y Servicios Públicos. Available from: http://www. hidricosargentina.gov.ar/biblioteca.php (June 2, 2013).

Jobb, G. 2008. Treefinder version of October 2008. Munich, Germany. Available from: http://www.treefinder.de.

Johns, G. C. \& J. C. Avise. 1998. A comparative summary of genetic distances in the vertebrates from the mitochondrial cytochrome b gene. Molecular Biology and Evolution, 15: 1481-1490.

Katoh, K. \& H. Toh. 2008. Improved accuracy of multiple ncRNA alignment by incorporating structural information into a MAFFT-based framework. BMC Bioinformatics, 9: 212.

Liotta, J. 2006. Distribución geográfica de peces de aguas continentales de la República Argentina. La Plata, Facultad de Ciencias Naturales y Museo, Universidad Nacional de La Plata. (Serie Documentos, n. 3. ProBiota).

Livingstone, D. M. \& A. F. Lotter. 1998. The relationship between air and water temperatures in lakes of the Swiss Plateau: a case study with palaeolimnological implications. Journal of Paleolimnology, 2: 181-198.

López, H. L., M. L. García \& C. Togo. 1991. Bibliografía de los pejerreyes argentinos de agua dulce: situación ambiental de la Provincia de Buenos Aires, A. Recursos y rasgos naturales en la evaluación ambiental. La Plata, Comisión de Investigaciones Científicas de la Provincia de Buenos Aires.

López, H. L., R. C. Menni, M. Donato \& A. M. Miquelarena. 2008. Biogeographical revision of Argentina (Andean and Neotropical Regions): an analysis using freshwater fishes. Journal of Biogeography, 35: 1564-1579.

Meraner, A., A. Venturi, G. F. Ficetola, S. Rossi, A. Candiotto \& A. Gandolfi. 2013. Massive invasion of exotic Barbus barbus and introgressive hybridization with endemic Barbus plebejus in Northern Italy: where, how and why? Molecular Ecology, 22: 5295-5312.

Modenutti, B., E. Balseiro \& C. P. Queimaliños. 2000. Ciliate community structure in two South Andean lakes: the effect of lake water on Ophrydium naumanni distribution. Aquatic Microbial Ecology, 21: 299-307.

Quirós, R. 1997. Argentinean lakes and reservoirs data base (ARLARE). Available from: http:// www.agro.uba.ar/users/ quiros (June 2, 2013).

Quirós, R., C. R. M. Baigún, S. Cuch, R. Delfino, A. De Nichilo, C. Guerrero, M. C. Marinone, S. Menu Marque \& M. C. Scapini. 1988. Evaluación del rendimiento pesquero potencial de la República Argentina I: Datos 1. Informes Técnicos del Departamento de Aguas Continentales. Instituto Nacional de Investigación y Desarrollo Pesquero, 7: 55. 
Ratnasingham, S. \& P. D. N. Hebert. 2007. Bold: The Barcode of Life Data System (http://www.barcodinglife.org). Molecular Ecology Notes, 7: 355-364.

Ringuelet, R. A. 1943. Piscicultura del pejerrey o Aterinicultura. Colección Agro, 6: 162.

Ringuelet, R. A. 1943. Piscicultura del pejerrey o Aterinicultura. Colección Agro, 6: 162.

Ringuelet, R. A. Aramburu, R. H. \& Alonso, A. A. 1967. Los Peces Argentinos de Agua Dulce. La Plata, Comisión de Investigación Científica.

Rohlf, F. J. 1996. Morphometric spaces, shape components, and the effects of linear transformations. Pp. 117-129. In: Marcus, L. F., M. Corti, A. Loy, G. Naylor \& D. E. Slice (Eds.). Advances in Morphometrics.Proceedings of the 1993 NATO Advanced Studies Institute on Morphometrics in Il Ciocco. New York, Plenum Publishing Corp.

Rohlf, F. J. 2003a. TPS Relw v. 1.35. Stony Brook, NY, Department of Ecology \& Evolution, State University of New York. Available from: http://ife.bio.sunysb.edu/morph/ (June 2, 2013).

Rohlf, F. J. 2003b. TPS Regr v. 1.28. Stony Brook, NY, Department of Ecology \& Evolution, State University of New York. Available from: http://life.bio.sunysb.edu/morph/ (June 2, 2013).

Rohlf, F. J. 2006. TPS Dig v. 2.10. Stony Brook, NY, Department of Ecology \& Evolution, State University of New York. Available from: http://life.bio.sunysb.edu/morph/ (June 2, 2013).

Rohlf, F. J. \& D. Slice. 1990. Extension of the Procrustes method for the optimal superimposition of landmarks. Systematic Zoology, 39: 40-59.

Rohlf, F. J. \& L. F. Marcus. 1993. A revolution in Morphometrics. Trends in Ecology and Evolution, 8: 129-132.

Servicio Meteorológico Nacional. Available from: www.smn. gov.ar (June 2, 2013).

Sommer, J., C. Conte-Grand, R. Cifuentes, E. Habit, V. Cussac \& G. Ortí. 2010. Phylogenies, species boundaries, and marine to freshwater transitions in South American silversides. American Society of Ichthyologists and Herpetologists Annual Meeting. Providence, Rhode Island, USA. 0618.

Somoza, G. M., L. A. Miranda, G. E. Berasain, D. Colautti, M. R. Lenicov \& C. A. Strüssmann. 2008. Historical aspects, current status and prospects of pejerrey aquaculture in South America. Aquaculture Research, 39: 784-793.

Strüssmann, C. A., D. O. Conover, G. M. Somoza \& L. A. Miranda. 2010. Implications of climate change for the reproductive capacity and survival of New World silversides (family Atherinopsidae). Journal of Fish Biology, 77: 1818-1834.
Strüssmann, C. A., T. Akaba, K. Ijima, K. Yamaguchi, G. Yoshizaki \& F. Takashima. 1997a. Spontaneous hybridization in the laboratory and genetic markers for the identification of hybrids between two atherinid species, Odontesthes bonariensis (Valenciennes 1835) and Patagonina hatcheri (Eigenmann 1909). Aquaculture Research, 28: 291-300.

Strüssmann, C. A., T. Saito, M. Usui, H. Yamada \& F. Takashima. 1997b. Thermal thresholds and critical period of thermolabile sex determination in two atherinid fishes, Odontesthes bonariensis and Patagonina hatcheri. The Journal of Experimental Zoology, 278: 167-177.

Tobler, M. \& E. W. Carson. 2010. Environmental variation, hybridization, and phenotypic diversification in Cuatro Ciénegas pupfishes. Journal of Evolutionary Biology, 23: 1475-1489.

Tsuzuki, M. Y., H. Aikawa, C. A. Strüssmann \& F. Takashima. 2000a. Comparative survival and growth of embryos, larvae and juveniles of pejerrey Odontesthes bonariensis and $O$. hatcheri at different salinities. Journal of Applied Ichthyology, 16: 126-130.

Tsuzuki, M. Y., H. Aikawa, C. A. Strüssmann \& F. Takashima. 2000b. Physiological responses to salinity increases in the freshwater silversides Odontesthes bonariensis and O. hatcheri (Pisces, Atherinidae). Revista Brasilera de Oceanografía, 48: 81-85.

Turner, G. F. 1999. What is a fish species? Reviews in Fish Biology and Fisheries, 9: 281-297.

Unmack, P. J., A. P. Bennin, E. M. Habit, P. F. Victoriano, \& J. B. Johnson. 2009. Impact of ocean barriers, topography, and glaciation on the phylogeography of the catfish Trichomycterus areolatus (Teleostei: Trichomycteridae) in Chile. Biological Journal of the Linnean Society, 97: 876-892.

Valentin, A., J. M. Sévigny \& J. P. Chanut. 2002. Geometric morphometrics reveals body shape differences between sympatric redfish Sebastes mentella, Sebastes fasciatus and their hybrids in the Gulf of St Lawrence. Journal of Fish Biology, 60: 857-875.

Villesen, P. 2007. FaBox: an online toolbox for FASTA sequences. Molecular Ecology Notes, 7: 965-968.

Wetzel, R. 1981. Limnología. Barcelona, Omega.

Submitted June 10, 2013 Accepted October 15, 2014 by Cláudio de Oliveira Published March 31, 2015 
